\title{
28
}

\section{Catchment, Stormwater and River Management in Cape Town, South Africa}

\section{Mark Obree}

In South Africa, a traditional approach to stormwater drainage has considered natural features such as rivers and wetlands as little more than convenient receptors for urban waste and storm runoff. Many rivers were canalized and wetland areas in-filled and drained to allow for urban development, dramatically altering their characteristics. This approach has inadvertently resulted in degradation of natural watercourses and precipitated a decline in water quality with concomitant adverse effects for human health, ecological integrity and community interaction with rivers and vleis (marshes).

Although already fairly well advanced in many developed countries, a paradigm shift in approach to stormwater and river management has recently been adopted in Cape Town, based on the philosophy of integrated catchment management. This chapter provides basic insight into the philosophy of urban catchment management and outlines some of the issues and challenges facing stormwater and urban river managers in Cape Town. It is hoped that the approach and recent experience in Cape Town will be of benefit to managers in other cities facing similar challenges.

Obree, M. 2004. "Catchment, Stormwater and River Management in Cape Town, South Africa." Journal of Water Management Modeling R220-28. doi: 10.14796/JWMM.R220-28.

(C) CHI 2004 www.chijournal.org ISSN: 2292-6062 (Formerly in Innovative Modeling of

Urban Water Systems. ISBN: 0-9683681-9-0) 


\subsection{Natural Drainage Systems and Impacts of Urbanization}

In Cape Town, the need for drainage of land on the Cape Flats became a high priority in the 50s and 60s (Murray, pending). The undulating sandy ground, together with a high water table and the traditional cold, wet winters led to chronic dampness, ill-health and discomfort, leading decision-makers to realize that something had to be done. Money and effort was put into draining the region, to improve conditions for the communities living in these areas at the time. Several examples of development made possible by providing drainage are available e.g. Blomvlei became Athlone, Tiervlei became Ravensmead and Paarden Eiland became an industrial estate (names that refer to water environments - Ed. note). Urban development has also required the building of roads along shorelines, with bridges at river crossings, thereby effectively preventing further meandering of estuaries and requiring ongoing manipulation e.g. Zandvlei and Silvermine River mouth.

Urbanization has therefore resulted in the loss of flood plains and ecological buffers, due to filling and development. Furthermore, river corridors have often been neglected, alien vegetation left uncontrolled and illegal dumping has taken place. The result of this abuse has in many cases led to occupation by vagrants and the loss of aesthetic, recreational and environmental value of natural drainage systems.

Apart from altering drainage systems to make land available for development as described above, urbanization itself has two other major impacts on the functioning of drainage systems. The first is the increase in the peakflow. With urban development, natural vegetation is removed and ground surfaces are covered by impervious surfaces e.g. roads, carparks, building roofs. Where flood plains have already been filled and development has taken place close to the rivers, there is often little option but to improve the hydraulic characteristics of the rivers by canalizing remaining portions, thereby aggravating the situation further by transferring the problem downstream.

The second major impact of urbanization is on the quality of water in our rivers i.e. pollution. There are many sources of urban pollution, the biggest being wastewater (effluent, spills, lack of sanitation etc) and solid waste (litter). The problem of pollution is particularly serious in areas where the rate of urban development has outstripped the rate at which the authorities have been able to provide services, such areas being called informal settlements. Apart from the water quality impact, the continuous discharge of treated sewage effluent into 
urban rivers also changes the flow characteristics of many rivers from seasonal to perennial. This results in significant and usually negative impacts on vegetation downstream and on the functioning of estuaries.

\subsection{Driving Forces and Community Needs}

The Cape Town municipal area has a population of approximately 3.2 million (City of Cape Town, 2002). This represents about $74 \%$ of the population of the entire Western Cape, although occupying less than $2 \%$ of the land area. Growth is highest amongst the poorer communities. Already $43 \%$ of the population are younger than 21 years and therefore largely economically unproductive. The trend is towards a younger, poorer population. Presently $32.5 \%$ of households live below and just above the poverty line of R1845 (US\$295)/month.

For stormwater management, this urbanization presents a huge challenge. In quantitative terms, peak runoff increases dramatically as catchments are hardened. Water quality is also affected, since changes in land use and inadequate levels of refuse and sewer services result in high pollution.

Cape Town is currently challenged by the housing and sanitation needs associated with high population growth. The current housing backlog is 240,000 units (City of Cape Town, 2001) and growing at a rate of 8,000 units per annum. Already there are about 100,000 informal dwellings, more than half of which have no access to sanitation at all, while the remainder have access to basic systems (e.g. buckets, communal toilets).

The continuous discharge of nutrient-rich, treated sewage, with its changes in the character of rivers from seasonal to perennial, results in the proliferation of undesirable vegetation growth and sediment accumulation. Increasing population densities and demand for more land for housing and other purposes, places pressure on the authorities to allow filling and encroachment of flood plain fringes. All of these impacts require careful management and mitigation strategies to maintain the integrity and functioning of the stormwater and river system.

Financial constraints place additional pressures on service delivery. Cost-effective planning of urban drainage systems, innovation, partnerships and the development of a sense of social and environmental responsibility are therefore all required.

The following are considered to be the major drivers for urban catchment, stormwater and river management: 
- population growth and the concomitant adverse impacts of development on natural drainage systems (i.e. increased runoff and pollution);

- heightened community expectations for good drainage, flood protection and ecologically healthy rivers;

- increased pressure on available open land within the city and the need to protect urban river corridors, wetlands and other drainage routes; and

- the water-scarce nature of the country and the increasing need for integrated urban water resource management.

Community needs from the service are as follows:

- good drainage;

- management of flood risks to residential, industrial and commercial properties;

- improved water quality in rivers, vleis, wetlands and receiving coastal waters;

- protection and enhancement of urban river corridors and wetlands as important natural features within the urban landscape;

- multi-functional, sustainable use of river corridors and drainage systems; and

- protection of urban water resources and the efficient and holistic management of urban water.

\subsection{Catchment Management Concept}

In South Africa, the concept of urban catchment management is relatively new and is still being translated from abstract concept into practical action. Some examples have proceeded through the planning stage, but few have reached implementation. In countries like Australia and the United States, the philosophy has been around for many years, and there are some good success stories.

Integrated catchment management has been defined as simultaneously a philosophy, a process and an implementation strategy to achieve a sustainable balance between utilization and protection of environmental resources in a catchment and to grow a sustainable society (WRC, 1996). Generally, the catchment management process addresses the needs of a catchment in terms of both land and water uses, and their optimization. Protection of the quantity and quality of water available for supply purposes is the primary objective when considering catchments on a regional scale. 
In the case of smaller urban catchments, catchment management focuses on different issues. Here the challenge is to minimize and deal with the impacts of urbanization on the natural drainage systems, to provide drainage and prevent flooding (due to increased runoff), prevent pollution (to avoid health risks and maintain ecological functioning) and to protect river corridors (as important natural features providing various benefits to society). However, as both water and financial resources are being stretched to their limits, so the need to protect and better utilize urban resources also becomes important.

Historically, the management of stormwater drainage (including rivers) in urban areas has been considered a simple drainage issue, to be dealt with by the engineering discipline alone. By definition, integrated catchment management requires a multidisciplinary approach with participation by various role players, including land use planners, waste managers, ecologists, wastewater and environmental scientists, and active community involvement.

The urban catchment management approach supports exploration of innovative ways of managing urban water, to achieve what is, in the long term, in the best interest of society as a whole. This includes consideration of all aspects of urban water management i.e. water supply, sewerage, groundwater and stormwater and is dealt with in more detail under the heading of Integrated Urban Water Management (IUWM).

\subsection{Legal and Institutional Aspects in South Africa}

The Constitution of South Africa (Act 108 of 1996) confirms the basic human right of individuals to an environment which is not harmful to their health or well being, together with the need for measures that prevent pollution and ecological degradation. The constitution also refers to local government's executive authority with respect to municipal planning, stormwater management in builtup areas, potable water supply systems and sewage disposal systems.

Section 156 (read in conjunction with Part B of Schedule 4) states that a municipality has executive authority and the right to administer stormwater management systems in built-up areas. In addition, a municipality has the right to exercise any power concerning a matter reasonably necessary for, or incidental to, the effective performance of its functions.

The National Water Act (Act 36 of 1998) is aimed at ensuring that the nation's water resources are wisely used, developed, conserved, managed and controlled. It provides for the development of water resource and catchment management strategies and the establishment of Catchment Management 
Agencies (CMAs) to allow for delegation of decision making to a regional or catchment level and involve local stakeholders in the process. The 19 Water Management Areas for which CMAs are to be established are shown in Figure 28.1. In the interim and until such time as powers are delegated, the Minister of Water Affairs and Forestry retains authority and responsibility for the management of the nations water resources.

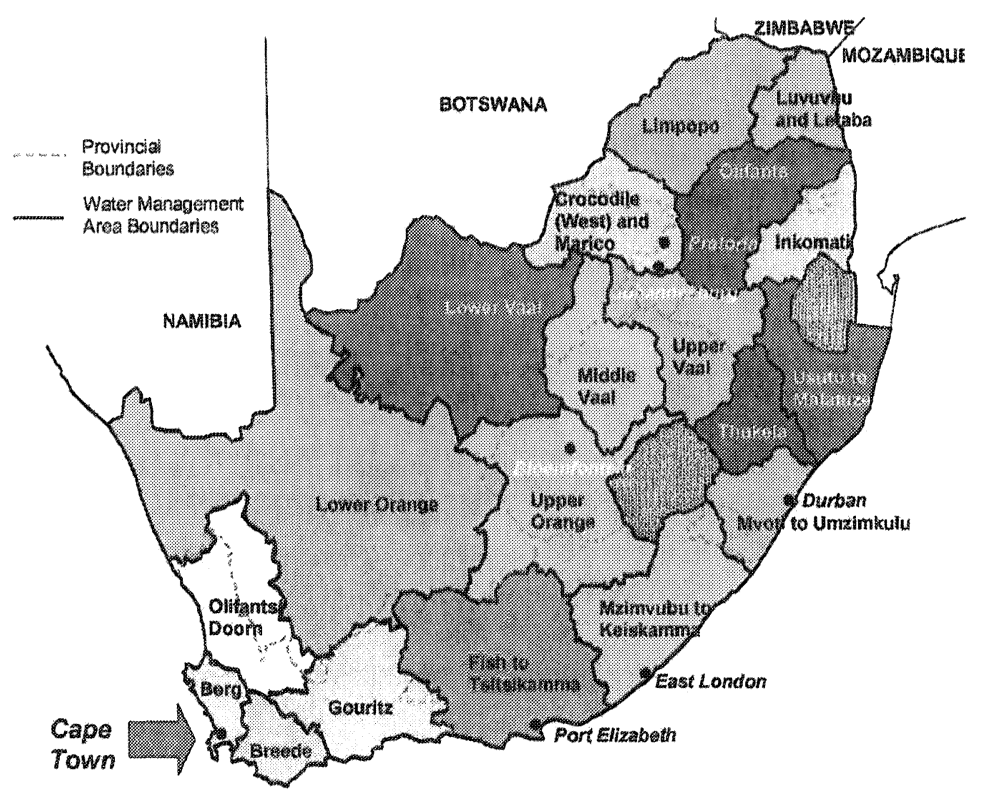

Figure 28.1 Nineteen water management areas for which CMAs are to be established.

The Local Government Municipal Systems Act (Act 32 of 2000) regulates municipal activities. The act inter-alia requires that municipalities carry out their functions and powers within the constitutional system of co-operative governance and that they have a duty to:

- promote a safe and healthy environment in the municipality,

- strive to ensure that municipal services are provided to the local community in a financially and environmentally sustainable manner,

- promote and undertake development in the municipality, and

- encourage the involvement of the local community.

The National Environmental Management Act (Act 107 of 1998), also known as NEMA, provides for co-operative environmental governance by 
establishing principles for decision-making on matters affecting the environment, institutions that will promote co-operative governance and procedures for co-ordinating environmental functions exercised by organs of the state/ and to provide for matters connected therewith. The following principles have particular relevance to stormwater management:

- development must be sustainable,

- pollution must be avoided or minimised and remedied, and

- responsibility for the environmental health and safety consequences of a policy, project, product or service exists throughout its life cycle.

The Environment Conservation Act 1989 (Act 73 of 1989) makes provision for the identification and management of activities that may have a substantial detrimental effect on the environment, as well as the promulgation of regulations regarding defined activities.

\subsection{The Need for Integrated Management}

The Constitution of South Africa (1996) reminds us that co-operative governance is not only a good idea, but also a constitutional requirement. This applies to co-operation between different spheres of government, but before this can happen, it should take place within each organization. In practical terms this involves communication and co-operation at various levels between service "silos".

Currently only $15 \%$ of Cape Town's raw water supply is abstracted from sources within the municipal area, while $85 \%$ is imported from beyond our borders (City of Cape Town, 2002). In the past, this led to a perception that our urban rivers are of little value other than as convenient receptors for sewage effluent and stormwater runoff. Increasingly it is now being recognised that these urban water resources are important, not only as potential sources for water abstraction, but also for their ecological, amenity and aesthetic values. A paradigm shift in thinking has occurred.

In order to achieve integrated management, services need to examine the fringe areas that fall outside their core functions but do not fall squarely into the core function of other service providers. An example would be the fouling of a canal by human faeces, which occurs when an informal settlement springs up adjacent to a canal. Water quality is seriously compromised, but which line function takes responsibility? Has housing failed by not providing houses to accommodate the needs? Has wastewater failed by not providing a sanitation 
service? Has stormwater failed by allowing pollutants to enter their system, resulting in ecological and health impacts downstream? This is typical of the sort of problem that requires willing co-operation of various role players to resolve.

Seemingly simple decisions on specific service issues can negatively impact other services. An example is budget cutting on street sweeping. While immediate savings are achieved on street sweeping, in the longer term very costly cleaning of underground reticulation is often needed, apart from the obvious negative impact on water quality downstream. Once again, issues need to be considered in a holistic and integrated manner if we are to achieve overall efficiency and sustainability.

The need for integrated management is particularly important for urban water management. The high level of pollution in urban stormwater systems, which detracts from their value as a resource (recreational, ecological, aesthetic and water supply) and impacts on ground and coastal water quality, must be addressed. This can only be successfully addressed through co-operation with other services and stakeholders.

In many cases individual services may already be addressing problems that cause negative impacts on other services, but these plans are not always discussed or communicated across service boundaries. This leads to frustration and poor relationships between services.

Co-operation is also required between different spheres of government. An example is the approval of a farm dam within the metropolitan area. The applicant would require a license from the Department of Water Affairs. Such license would require the determination of the ecological water reserve. Other environmental impacts would require the involvement of the Provincial Department of Environment. The Local Authority would also have a vital interest in the project in so far as it may affect downstream residents and drainage systems. A practical mechanism for collaborative decision-making is therefore required.

\subsection{How to Achieve Integrated Management of Urban Water}

Integrated urban water management (IUWM) should start with the building of awareness of broader issues by providing mechanisms to facilitate communication between role players. By so doing, a culture of openness and co-operation is developed. 
Almost all involved in planning, regulating, delivering and using water supply, sanitation and stormwater services have a role to play in achieving integration. National and Provincial authorities play a role at a strategic and regulatory level. Research institutions, academics and specialist service providers can also assist, particularly regarding technological development. Communities are responsible for the correct and efficient use of water, wastewater and stormwater services and, in line with the new participative style of governance, need to be engaged before decisions affecting them are made.

Within a municipality, the primary role players in IUWM are those involved in water supply, wastewater and stormwater. Figure 28.2 illustrates interaction between these functions in the urban water cycle. This should involve the strategic planners and policy makers as well as operational staff in the regional/ district offices. The improvement of water quality and amenity value of urban stormwater and river systems however involves many other role-players such as spatial planners, open space managers, solid waste managers, law enforcement, industrialists, farmers, property owners and the general public.

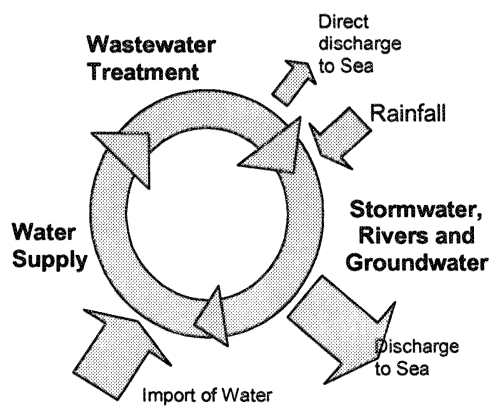

Figure 28.2

Various awareness and capacity building processes are necessary to disseminate information and raise awareness. Guideline documents and clear strategies and policies for various aspects of urban water are necessary to promote understanding and efficient management.

Communication and co-ordination of urban water issues can take place through committee or forum meetings. While these meetings do provide an opportunity for integration, there is a danger that other "core business" priorities result in poor attendance. The whole process is thereby frustrated and the efforts and enthusiasm of others is undermined. There is therefore a need for genuine commitment amongst all key role players to co-operate and provide regular and meaningful input for co-ordination meetings to be successful. 
The basic unit for management of stormwater and urban river systems is the natural drainage catchment. If political, administrative and service delivery boundaries coincided with catchment boundaries, the management of stormwater and river systems would be simplified. However, in most municipalities, this is not the case. In Cape Town, catchment boundaries are very different to those of district, ward and sub-council areas.

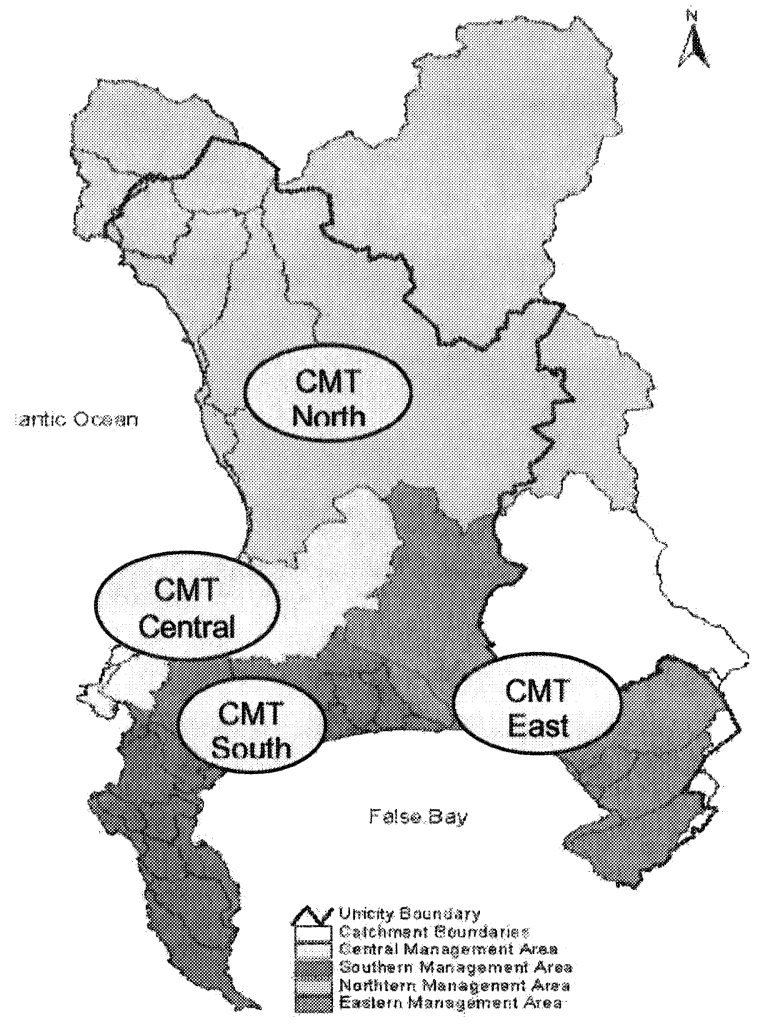

Figure 28.3

In order to overcome this problem and promote integrated management within the municipality, Cape Town is establishing catchment based integrated management teams. Each team will deal with a group of drainage catchments as shown in Figure 28.3 and perform the following functions:

- steering the compilation, implementation and monitoring of Catchment and River Management Plans;

- reviewing river and coastal water quality monitoring data and 
recommending corrective action;

- co-ordinating stormwater and river management related capital and maintenance programs of the various functions represented;

- nominating officials to interface with external stakeholders on catchment related issues (e.g. through catchment forums);

- interfacing with Sub-Councils through sub-council co-ordinators; and

- communicating aspects of development applications which affect catchment, stormwater or river management in their region.

But co-ordination of urban Catchment, Stormwater and river activities between the local authority, external role players and community groups is also necessary. Catchment Forums are voluntary bodies that play an important role in this regard. Another voluntary association, focussed on the maintenance of seawater quality is active in Cape Town, the Cape Metropolitan Coastal Water Quality Committee. The terms of reference of this committee are essentially to liaise and co-ordinate amongst members on all matters relating to water quality such as monitoring, standards, procedures and research. Annual reports are published and distributed to interested parties and these attract significant media and public attention.

Integration of knowledge, needs, aspirations \& disciplines to achieve holistic management of urban catchments is a daunting task. Catchment Forums have played an important role in this process. It is within these structures where role players of very different interests have made their voices heard. However, there are various barriers to integration that need to be recognised and overcome. These include:

- misunderstanding of discipline specific concepts by other disciplines or participants;

- fear of individuals to discuss issues which fall outside of their area of expertise or "comfort zone";

- the perception that integration equates to extra costs, delays and inefficiency

- lack of focus (typical of environmental scientists) vs. too narrow a focus (engineers); and

- perception that education and capacity building should be regarded as a low priority which cannot bear fruit quickly.

In conclusion, it is vitally important that stormwater and urban river managers engage with their counterparts responsible for other services. IUWM can best be achieved if service delivery structures move away from discipline based units, to multidisciplinary teams taking responsibility for the full urban 
water cycle. The quantity and quality of stormwater is directly linked to activities taking place within the Catchment areas. Good communication channels and co-ordination mechanisms are therefore essential if they are to ensure effective urban drainage with safe and healthy rivers and coastal waters.

\subsection{The Catchment, Stormwater and River Management Strategy in Cape Town}

The Cape Town municipal drainage system comprises approximately:

* $2,487 \mathrm{~km}^{2}$ of catchment areas (including 17 individual catchments

$>20 \mathrm{~km}^{2}$ each),

* $1500 \mathrm{~km}$ rivers, streams and canals,

* $5000 \mathrm{~km}$ underground pipes and culverts,

* 300 stormwater detention ponds,

* $300 \mathrm{Ha}$ wetlands, and

* $50 \mathrm{Ha}$ estuarine areas.

Responsibility for management of this system rests in the hands of the Catchment, Stormwater and River Management (CSRM) Branch of the Transport, Roads and Stormwater Directorate of the City of Cape Town. This includes management of the stormwater reticulation system, open watercourses, wetlands, groundwater, vleis and estuaries in terms of their hydrological functioning for drainage, flood control, ecological and social needs and as a potentially important water resource.

Effective stormwater drainage with safe and healthy rivers is the seemingly simple vision statement which guides the Catchment, Stormwater and River Management service in Cape Town. The mission is to minimise flooding of property and improve the water quality and health of our rivers, wetlands, vleis and coastal waters through integrated catchment management for the benefit of the people of Cape Town.

The following are the desired outcomes of the service:

- effective stormwater drainage (including upgrading of existing infrastructure);

- managed flood risks (for residential, industrial and commercial properties as well as transport systems);

- improved water quality (surface, ground and coastal waters);

- ecologically healthy rivers, vleis and wetlands; and

- multi-functional, sustainable use of river corridors and stormwater drainage facilities. 
The CSRM Branch has responded to the challenges facing the city by formulating a strong strategic direction, embarking on integrative measures with other service providers and statutory authorities and by being pro-active in communicating awareness with respect to water related issues. The strategy was widely publicised for public comment and adopted as Council policy in July 2002. Each strategic focus area carries with it a supporting program as tabulated below.

Table 28.1 Strategic focus areas and supporting programs.

\begin{tabular}{|c|c|}
\hline Strategic Focus Areas & Supporting Programmes \\
\hline $\begin{array}{l}\text { Holistic Planning and } \\
\text { Management }\end{array}$ & $\begin{array}{l}\text { Catchment, Stormwater and River Planning } \\
\text { Integrated Urban Water Management }\end{array}$ \\
\hline $\begin{array}{l}\text { System Development, } \\
\text { Upgrading and Maintenance }\end{array}$ & $\begin{array}{l}\text { Stormwater Management Guidelines and Design Criteria } \\
\text { for New Developments } \\
\text { Risk Based Approach to Upgrading and Maintenance } \\
\text { Infrastructure Management System } \\
\text { Environmentally Sensitive River Maintenance }\end{array}$ \\
\hline $\begin{array}{l}\text { Public Safety and } \\
\text { Environmental Protection }\end{array}$ & $\begin{array}{l}\text { Flood Disaster Mitigation } \\
\text { Water Pollution Abatement }\end{array}$ \\
\hline Information Management & $\begin{array}{l}\text { Information Systems } \\
\text { Data Bureau Services }\end{array}$ \\
\hline Regulatory & $\begin{array}{l}\text { Control of Development near Watercourses } \\
\text { By-Laws } \\
\text { Tariff Funding Options }\end{array}$ \\
\hline Relationship Management & $\begin{array}{l}\text { Management Integration Mechanisms } \\
\text { Customer Care } \\
\text { Staff Development } \\
\text { General Education Initiatives } \\
\text { Partnership Development }\end{array}$ \\
\hline
\end{tabular}

The change in approach to urban drainage in Cape Town over the last decade is profound. It has moved from dealing with urban runoff as a simple drainage issue, dealt with by the engineering discipline alone, to the holistic and integrated management of rivers and their catchments as ecologically functioning systems and unique assets of our urban communities.

Recognition of achievement and celebration of success is important. Awards have been received as follows:

Green Trust Award (2000): Hout Bay River Upgrade

SAICE Excellence Award (2000) and Impumelelo Innovations Award (2001): Moddergatspruit Upgrade

Cape Times/Caltex EnvironmentalAward(2002): GreaterZandvlei 
Estuary Partnership

Green Trust Award (2003) and SAICE Excellence Award (2002):

Silvermine River Flood Control Project

\section{References}

Murray, A.S., pending. Much Water under Many Bridges: A History of the Catchments, Rivers and Drainage Systems of Greater Cape Town: Pending Publication, A S Murray, P O Box 198, Rondebosch, Cape Town, 7701, RSA

City of Cape Town, 2002. Introduction to the Economic Development and Tourism Directorate: 2002/3, Publication of the Economic Development and Tourism Directorate, City of Cape Town, P O Box 16548, Vlaeberg, 8018, RSA

City of Cape Town, 2001. Water Services Development Plan: Dec 2001, Publication of the Water Services Directorate, P O Box, 16548, Vlaeberg, 8018, RSA

WRC, 1996. The Philosophy and Practice of Integrated Catchment Management: Department of Water Affairs and Forestry and Water Research Commission: WRC Report TT 81/96: 1996: ISBN 1868452689

\section{Bibliography}

Proceedings: IUWM Symposium: 1st Feb 2003: UWC and City of Cape Town Proceedings: Co-operative Urban Catchment Management Symposium 2000: UWC/ CMC:29th Jan 2000

Proceedings: 4th Urban Catchment Management Symposium: UWC/CCT: 9th Feb 2002

Water Research Commission: Report TT 155/01: Guidelines for Appropriate Management of Urban Runoff in SA

Proceedings: 8th International Conference on Urban Storm Drainage: Sydney: Aug/ Sept 1999

City of Cape Town: Cape Town's Economy: Current Trends and Future Prospects: 2001

City of Cape Town: Catchment, Stormwater and River Management Strategy 20022007

City of Cape Town: Catchment, Stormwater and River Management Business Plan: June 2002

City of Cape Town: Catchment, Stormwater and River Management Service: Discussion document on Functional Mandates and Responsibilities: 14 May 2002 